\title{
Predatory Pricing in Business Activities in the Telecommunication Field
}

\author{
Desy Putri Utami ${ }^{*}$, Budi Santoso ${ }^{2}$, Rinitami Njatrijani ${ }^{3}$ \\ \{desyputriutami@yahoo.com ${ }^{1}$, budi.santoso@live.undip.ac.id ${ }^{2}$,rinitami@live.undip.ac.id ${ }^{3}$ \}
}

Fakultas Hukum, Universitas Diponegoro, Jl. Prof. H. Soedarto, S.H., Semarang, Indonesia $50275^{1}$

\begin{abstract}
Predatory pricing is a form of practice of selling goods or services at very low prices, with the aim of getting rid of competitors or inhibiting the entry of new competitors in a business field. By law in Indonesia, the use of predatory pricing practices is contrary to Law Number 5 of 1999. Advertising practices in competitive prices and a number of bonuses offered by cellular operators as telecommunications business players are indicated as a consumer withdrawal strategy. The low pricing strategy in advertising practices is indicated as the desire of telecommunications business players to monopolize the market to protect their position and close the gap for new business actors to enter the market. In connection with this matter, a study of one of the telecommunications business operators in Indonesia has been carried out with the aim of finding out predatory pricing in the telecommunications sector and government regulations and actions regarding predatory pricing practices in the telecommunications sector. The results of the study are expected to encourage the government to make regulations governing the minimum and maximum cost limits imposed by telecommunications businesses. To regulate the practice of predatory pricing and improve service and quality of telecommunications services. To regulate the practice of predatory pricing and improve services and the quality of telecommunications services.
\end{abstract}

Keywords: Predatory Pricing, Telecommunications, Advertising

\section{Introduction}

An economy that is developing towards market orientation leads to competition in various activities in the national economy. Competition has the potential to drive an increase in the number of business actors which in turn will increase the number of offers and types of goods available in the market. In order to make the business competition carried out fairly, a fair business competition climate is needed. In relation to the rapidly developing telecommunications sector, every community already has one or even more than one telecommunications device in the form of a cell phone.

With the growing needs in the field of telecommunications for the community, the telecommunications operators began competing to offer their products with a variety of advertisements such as giving an offer in the form of "one-hour free two-hour telephone". With this advertisement, the public will mostly choose the telecommunication operators that provide the best and cheapest offer. This is where telecommunications operators begin to think of ways to make people use their services which results in many operators offering crazy prices beyond the calculation of their own production, which ends with predatory pricing behavior of the service providers. 
As in the Indosat Ooredoo advert which in 2016 imposed a telephone tariff of IDR 1/second to all 24-hour nonstop operators which, if linked to Article 20 of Law Number 5 of 1999, can be proven that Indosat Ooredoo conducts selling loss on its products, which can be seen from applying a tariff of IDR 1/second that will produce IDR 60/minute to other operators, while the interconnection tariff set by the government is IDR 250/minute, which makes the tariff price of IDR $1 /$ second no longer reasonable (non-reasonable) and Indosat companies should also experience a loss of IDR 190/minute, which is impossible for a company to do if it does not have strong capital power to subsidize tariffs so that they are below cost and should be suspected that aims to shift market competitors.

In business activities, fraudulent competition is something that can not be avoided by business actors. On one party can provide benefits and cause harm to other parties. Competition occurs when there are several entrepreneurs engaged in the same/similar field of business, jointly running a company in the area of operation (same marketing), each of them trying as much as possible to exceed the others to obtain maximum profit.[1]

Competition can be viewed from the side of the law where in competition there will always be a tendency to bring down one another with another party which in this case can be in the form of unlawful actions.[2] One of the actions against the law that is usually carried out by business actors is Predatory Pricing or commonly referred to as selling loss.

Predatory pricing is the practice of selling goods or services at very low prices, with the intention of removing competitors from the relevant market, or creating barriers to entry to potential new competitors. If competitors or potential competitors cannot maintain the same or lower prices without loss, then business actors will be eliminated from competition or choose not to compete in the relevant market.[3]

In the event of predatory pricing or selling loss can have a monopolistic impact on business actors doing so. Monopoly is a market situation where only one business actor or one group of business actors controls a production and/or marketing of goods and/or the use of certain services, which will be offered to many consumers resulting in the business actor or group of business actors being able to control and control level of production, price and at the same time marketing area. From the provisions of Article 17 of the Anti-Monopoly Act, it turns out that not all monopoly activities are prohibited. Only monopolistic activities that fulfill the elements are prohibited.[4]

In guaranteeing development and security in business competition, Law Number 5 of 1999 concerning the prohibition of monopolistic practices and unfair business competition was issued. The implementation of Law Number 5 of 1999 is considered effective in becoming the basis for driving economic restructuring and can create a culture of competition so that it can continue to encourage and increase the number of healthy business actors in the future. One form of anti-competitive behavior that is of concern in Law Number 5 of 1999 is predatory pricing.

In Law Number 5 of 1999 concerning the prohibition of monopolistic practices and unfair business competition in Article 20 says that:[5]

"Business actors are prohibited from supplying goods and or services by selling at a loss or setting a very low price with a view to getting rid or deadly competitors in the relevant market so that it can result in monopolistic practices and or unfair business competition."

Therefore, based on this law, business actors can obtain an explanation and a better understanding of this predatory pricing behavior. 
Based on the description above, the author's reason to explore the problem becomes research in the framework of compiling legal writing on the Legal Studies Scholarship Program at Diponegoro University in Semarang with the title "Predatory Pricing in Business Activities in the Telecommunications Field based on Law No. 5 of 1999"

Based on the background description above, there are several issues that will be examined and formulated as follows:

1. How is the practice of advertising in the field of telecommunications which is indicated as the practice of "Predatory Pricing?"

2. How is the proof regarding "Predatory Pricing" based on Law Number 5 of 1999 ?

\section{Method}

The approach method used in this study is an empirical juridical approach. The juridical approach is intended that this research be reviewed from the regulations which constitute secondary data and empirical approaches namely legal research that uses primary data.[6] Therefore the approach developed is to describe the applicable laws and regulations related to the practice of implementing positive law.[7]

\section{Results and Discussion}

\subsection{Advertising Practices in the Field of Telecommunications Indicated as Predatory Pricing Practices}

In ancient Rome, advertisements were used in the form of stone stamps, in 1650 The Weekly News began to include advertisements. Initially the advertisements were still veiled, because there were still no more professional ways to handle them.[8] The development of advertising increased when the industrial revolution occurred. Print advertising grew faster in Britain when Richard Steele published a newspaper titled Tatler in 1709. In 1711 Richard Steele together with Joseph Addison published the Spectators newspaper. The advertising business also grew rapidly in the 1920s when the print world began publishing printed material in color.[9]

After World War II, advertising in television media developed rapidly and continued to establish itself as the largest advertising media. Because of its nature that is able to present sound as well as motion pictures, this media began to be viewed by advertisers. Recorded in history, in 1948 the first television commercial spearheaded by J. Walter Thompson began airing. In the beginning, television commercials were still veiled. However, in the end, television advertisements became more open. in 1955 color television was introduced.[9] Today, advertising is growing rapidly. Advertising is much influenced by technological developments. Now, advertising has become big business. Creativity began to vary, so advertising became more varied. The media used are not only limited to newspapers, magazines, radio and television, but also using a variety of other media.

The ability to make good advertisements and be able to attract the attention of potential consumers is not easy. In addition to advertising designer creativity, mobile operators should also be able to understand the characteristics of the target market to be achieved. One of the characteristics of Indonesian people like what is called "free" or "free". A culture that likes 
free stuff is not only at the lower class level, but also reaches the middle to upper classes who are not spared from having this same pleasure. Not surprisingly, many of the operators present a variety of bonuses, ranging from free sms, credit, cheap rates to free calls which are then delivered through attractive advertisements with several well-known figures.

The bonus strategy and low tariff system are used by cellular operators in order to increase the loyalty of prepaid card users. Although these low tariffs are not the only reason for customer loyalty to cellular operators, which is caused by the average consumer stating that cellphone numbers have already been spread, and if there is a change in the cellphone number, this consumer feels reluctant to have to inform the new number again to the relations, colleagues, friends.

Consumers are divided into two groups, namely trial consumers, and permanent consumers. Trial consumers can turn into permanent consumers if they are satisfied with the service of the chosen cellular operator. And so are the reasons consumers remain to survive or move from these cellular operators. Various bonuses and freebies may not necessarily all make all consumers interested because of differences in needs.

Table 1. Basic telephone tariffs for fellow prepaid Semarang area operators

\begin{tabular}{llll}
\hline No & Operator & Product & average rate per minute \\
\hline 1 & Telkomsel & SimPATI & IDR 31.33 / minute \\
\hline 2 & Indosat & IM3 Ooredoo & IDR 10/ minute \\
\hline 3 & XL Axiata & IDR 333.5 / minute \\
\hline 4 & Smartfren & IDR 240 / minute \\
\hline 5 & 3 & IDR 40 / minute \\
\hline \multicolumn{2}{c}{ Source: based on telephone data packages offered by operators }
\end{tabular}

Cheap tariffs are now becoming a pleasure in competing with the use of reaching more consumers or increasing market share that looks still wide open to work on. With the impact if in the telecommunications business is running naturally, certainly consumers will benefit from getting many choices to determine which telecommunications operators will be the choice. One of which is possible with the low tariffs offered by cellular operators as consideration for selection. In addition, consumers also expect to get good service, variety, quality and affordable prices. However, with the war in the telecommunications business tariffs at this time also need to be aware of.

This has the potential for violations of Law Number 5 of 1999 concerning Prohibition of Monopolistic Practices and Unfair Business Competition, especially in the provision of Article 20 which states that business actors are prohibited from supplying goods and or services by selling or setting prices in a very low prices with the intention of eliminating or shutting down competitors' businesses in the relevant market, so that it can result in monopolistic practices and or unfair business competition. Very low price offer with a view to getting rid of business competitors, is called Predatory Pricing.

Examples of telecommunications advertisements that indicate predatory pricing:

1. Indosat in 2016

2. $\mathrm{XL}$ in 2017

3. IM3 Ooredoo in 2017

Table 2. Ads that indicated predatory pricing throughout 2016-2018 


\begin{tabular}{cccc}
\hline No & Year & $\begin{array}{c}\text { The number of ads indicated } \\
\text { predatory pricing }\end{array}$ & percentage \\
\hline 1 & 2016 & 1 & $33 \%$ \\
\hline 2 & 2017 & 2 & $67 \%$ \\
\hline 3 & 2018 & - & - \\
\hline 4 & 2019 & - & $100 \%$ \\
\hline Total & & 3 &
\end{tabular}

\subsection{Proof of Predatory Pricing Based on Law Number 5 of 1999}

In addition to Article 20, the prohibition on pricing is also regulated in Article 7 of Law Number 5 of 1999 concerning prohibitions on pricing below market prices. However Article 7 and Article 20 will be applied differently by the Commission depending on the facts of the case by case. Article 7 requires an agreement with a competing business actor to set a price below the market price, while Article 20 does not specify an agreement.

In Article 20 can be broken down into several elements contained in the Article:[8]

1. Elements of Business Actors. The definition of business actors as referred to Article 1 number 5 , which is every individual or business entity, whether in the form of a legal entity established and domiciled or carrying out activities within the Indonesian jurisdiction, either alone or jointly through an agreement, organizes various business activities in the economic field.

2. Supplier Element. The meaning of supplying as referred to the explanation of Article 15 , which is to supply supplies, both goods and services, in the sale and purchase, leasing, leasing, and leasing activities.

3. Element of Goods. Definition of goods according to Article 1 number 16 is every object, both tangible and intangible, both movable and immovable, which can be traded, used, used, or utilized by consumers or business actors.

4. Service Element. Service Definition according to Article 1 number 17 is every service in the form of work or achievement traded in the community to be used by consumers or business actors.

5. Elements of Sale and Loss. Sale and loss is the selling price determined by the business actor below the expected cost.

6. Extremely Low Price Elements are prices set by business actors that are unreasonably low.

7. With the intention to mean that the activity is carried out with a desire or purpose.

8. Eliminating or Shutting Down means removing or eliminating a competing business actor from the relevant market or closing down his business.

9. Competitor Business Element is another business actor's business in the same relevant market.

10. Market Elements, According to Article 1 number 9, market is an economic institution where buyers and sellers can directly or indirectly carry out trade in goods and or services.

11. Related Market Elements are markets related to the reach or certain marketing areas by business actors for the same or similar goods and or services or substitutions of said goods and/or services.

12. Monopolistic Practices, according to Article 1 number 2, is the concentration of economic power by one or more business actors which results in the mastery of the production and/or marketing of certain goods and or services, which creates unfair business competition and can harm the public interest. 
13. Elements of Unfair Business Competition, according to Article 1 number 6, is competition between business actors in carrying out production and or marketing activities of goods and or services carried out in a way that is dishonest or under the law or impedes business competition.[8]

Based on Law Number 5 of 1999, KPPU has the authority to impose sanctions on business actors violating the provisions of Article 20 in the form of administrative sanctions, principal criminal penalties, and additional penalties can be imposed in Article 47, Article 48, and Article 49.

The impact of predatory pricing practices;

a. If it is successful

In the success of the practice of predatory pricing carried out by cellular operators will have an impact, including:

1. Operators, predatory pricing in the telecommunications business has an impact on operators in the form of their business being eliminated or even dead from the market, and experiencing losses due to the loss of consumers who turn to companies that carry out these predatory pricing actions.

2. Consumers, at the beginning of the practice of predatory pricing this can be beneficial because of the low price fixing, but over time will cause losses after the predatory pricing actors set high prices after getting rid of competitors in the market, and consumers have no other choice in selecting operators cellular because the exclusion of other companies.

\section{If it fails}

Before a company conducts predatory pricing practices, it should consider two conditions in conducting predatory pricing practices, namely the company must be sure that its competitors will die first compared to the company, and believe that the profits after the implementation of predatory pricing will exceed losses during the predatory pricing practice. However, despite taking into account the requirements and being sure of what will be done, there will still be a gap to fail, and in doing this predatory pricing practice also has the possibility of failure to do so, if the predatory pricing practice fails to be carried out by the cellular operator then the operator will suffer loss, setback, lose consumer confidence, or even go bankrupt.

The resource person said that if the strategy was accompanied by an increase in the quality of the product it would be able to increase the share of the company. However, if it only lowers prices to make no sense, so customers will switch because they are interested in low prices, then the competitor has violated the rules set out in Law No.5 of 1999, and BRTI should reprimand them.[9] Regarding losses incurred by operators when competitors engage in predatory pricing practices, the resource person said that when looked in closer, not all customer segments will turn away when competitors apply the strategy, maybe only in the Youth segment that is still not sustainable in financial terms. But more or less will certainly cause losses, because on one hand the company must maintain Net Income, so it will not be able to follow the strategy, so that loyal customers will move, causing losses. [9]

In the role of the government, the public expects very much the KPPU's decision to be able to make the telecommunications business not only benefit the cellular operator company, but also pay attention to the services provided to the quality telecommunications service users. The informant said that during the war the price of telephone and SMS at that time, the government had played an active role by providing a minimum tariff limit, so operators could 
not provide tariffs below the tariffs that had been set. Then on July 11, 2003, through Ministerial Decree Number 31 of 2003, established the birth of the BRTI (Telecommunications Regulatory Agency) This institution was intended to be able to regulate, supervise and control telecommunications services in Indonesia equally for all cellular operators, both BUMN and private. Telecommunications businesses are required to submit information to BRTI regarding the development of the telecommunications business being carried out. However, the establishment of the BRTI is indeed one of the provisions politically required by the DPR to the government to be able to make telephone tariff adjustments. Which means that the formation of BRTI does not have to be telephone tariffs that can be adjusted directly.

Related to the telephone tariff adjustment problem, which basically determines the ITRB not directly related to the telephone tariff adjustment because this tariff adjustment is directly related to the costs incurred by the telecommunications operator, including the rebalancing method which must be used as a basis tariff setting by the organizer.

The resource person was of the opinion that BRTI had carried out its role quite well, by carrying out supervision of telecommunications operators quite tightly. And enforcing regulations governing the procedures for running a telecommunications business. [9]

\section{Conclusion}

1. Low tariffs offered by cellular operators to consumers through telecommunications advertisements have indeed become a special pleasure in competition, such as reaching more consumers to increase market share within the telecommunications company concerned, and which should then be watched out for. This kind of competition has the potential to result in monopolistic practices and unfair competition among the telecommunications business actors. The tariff war offered through various types of advertisements has led to lower telecommunications costs offered by operators. At a glance, it does seem to benefit consumers who use it, and in reality instead, the quality and service received by consumers are also increasingly felt to be directly proportional to the decreasing price of telecommunications offered. Although a number of telecommunications advertisements are indicated to have carried out predatory pricing practices, but based on the research, they so far are still at a reasonable level.

2. Regulations on predatory pricing use Law Number 5 of 1999 concerning Prohibition of Monopolistic Practices and Unfair Business Competition. Article 20 clearly states that business actors are prohibited from carrying out acts of selling at very low prices with the intent and purpose resulting in monopolistic practices and or unfair business competition. Meanwhile, Article 7 states that business actors are prohibited from making agreements with competitors to set prices below market prices resulting in unfair business competition. In Law Number 5 of 1999 also stipulates sanctions for the practice of predatory pricing in Article 47 for administrative sanctions, Article 48 for basic crimes, and Article 49 for additional crimes. Then, the role of the government to respond the predatory pricing is coming from the KPPU's decision to make the telecommunications business not only concerned with profits but also concerned with services provided to consumers. On July 11, 2003, through 
Ministerial Decree No. 31 of 2003 stipulated the birth of BRTI to regulate, supervise, and control telecommunications services in Indonesia.

\section{Suggestion}

1. Telecommunications companies need to be more focused on the level of quality and service intended for consumers rather than obsessed with attracting more consumers, because the demand for telecommunications services will still not decline, and even tend to increase. Therefore, what is needed by telecommunications companies is to retain consumers by offering better quality and service.

2. The government needs to start making regulations to regulate the upper and lower limits of cellular telecommunications costs in accordance with the production costs incurred by companies The regulations are meant to control telecommunications costs so as not to be too high and not too low, and to prevent the practice of predatory pricing which results in monopoly and unfair business competition in the business of cellular telecommunications. 


\section{References}

[1] H. M. N. Purwosutjipto, Pengertian Pokok Hukum Dagang Jilid 6. Jakarta: Djambatan, 2003.

[2] Y. Utami, W. and Adipradana, Pengantar hukum bisnis: dalam perspektif teori dan praktiknya Indonesia. Jakarta: Jala Permata Aksara.

[3] I. D. G. R. Mada and A. S. Indrawati, PRAKTIK JUAL RUGI (PREDATORY PRICING) PELAKU USAHA DALAM PERSPEKTIF PERSAINGAN USAHA. Bali: Bagian Hukum Bisnis Fakultas Hukum Universitas Udayana, 2013.

[4] T. P. Kurnianingrum, "Kajian hukum atas merger CDMA FlEXI dan ESIA dalam persaingan usaha bisnis telekomunikasi seluler (legal review of merger CDMA ESIA and FLEXI business competition in telecommunications cellular)," Negara Huk. Membangun Huk. untuk Keadilan dan Kesejaht., vol. 3, no. 1, pp. 59-76, 2016.

[5] Law Number 5 of 1999 concerning the prohibition of monopolistic practices and unfair business competition. .

[6] R. H. Soemitro, Metodologi Penelitian Hukum dan Jurimetri. Jakarta: Ghalia Indonesia, 1988.

[7] R. Widyatama, Pengantar periklanan. Yogyakarta: Pustaka Book Publisher, 2007.

[8] Komisi Pengawas Persaingan Usaha, Pedoman Pelaksanaan Pasal 20 Tentang Jual Rugi (Predatory Pricing). Jakarta: Komisi Pengawas Persaingan Usaha, 2009.

[9] Interview with Hary Susilo, Human Resources Department (HRD) of PT. Telkomsel Semarang region, (Semarang: November 11, 2019). . 